\title{
EMOSI POSITIF MANUSIA PERSPEKTIF AL-QUR'AN DAN APLIKASINYA DALAM PENDIDIKAN
}

\author{
MIFTAH ULYA \\ STAI Diniyah Pekanbaru-Riau \\ e-mail: miftahulya@yahoo.co.id
}

\begin{abstract}
Abstrak: Manusia adalah makhluk unik yang memiliki emosi. Emosi melatarbelakangi perbuatan dan kemauannya juga terjalin erat dengan segenap kepribadian yang memberikan warna pada suasana hati. Emosi merupakan suatu keadaan biologis dan psikologis serta serangkaian kecenderungan untuk bertindak yang ada pada diri hampir di setiap tindakan manusia. Di dalam al-Qur'an ungkapan "emosi manusia" terkait langsung dengan prilaku manusia, baik sebagai makhluk individual (fardiyah) maupun sosial (jama'iyah), baik pada aspek informasi masa lampau, kini, maupun masa depan. Secara umum, digambarkan ekspresi emosi yang menyenangkan, dan ada pula ekspresi emosi tidak menyenangkan. Dalam al-Qur'an terdapat banyak keterangan dan uraian tentang berbagai emosi dasar yang dirasakan manusia. Rasa takut, senang atau bahagia, dan emosi lainnya. Di tengah hiruk pikuknya persoalan emosional yang tidak luput dari proses transfer ilmu di ranah pendidikan yang dapat berpengaruh kepada krisis keteladanan sebagai figur dalam hal edukasi, maka dengan mengedapankan emosi positif sebagai acuan dasar yang disampaikan dalam al-Qur'an, akan dirasakan sebagai solusi yang mampu memberikan one-one solution pada dunia pendidikan dewasa ini.
\end{abstract}

Kata Kunci: Emosi, Al-Qur'an, Aplikasi, Pendidikan.

Abstract: Humans are unique creatures that have emotions. The emotions behind the actions and willingness are also closely intertwined with all the personalities that give color to the mood. Emotion is a biological and psychological state and a series of tendencies to act that exist in oneself almost in every human action. In the Qur'an, the phrase "human emotion" is directly related to human behavior, both as individual beings (fardiyah) and social (jama

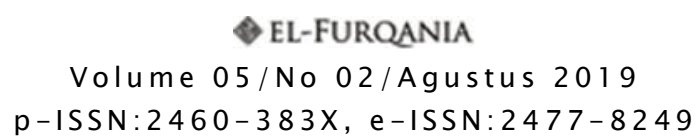


'iyah), both in the aspects of the past, present, and future information. In general, described pleasant emotional expressions, and there are also unpleasant emotional expressions. In al-Quran there are many explanations and descriptions of various basic emotions felt by humans. Fear, happy or happy, and other emotions. In the midst of the hustle and bustle of emotional problems that do not escape the process of transfer of knowledge in the realm of education that can affect the exemplary crisis as a figure in education, then by putting positive emotions as a basic reference, it will be felt as a solution that can provide one-one solutions to the world education today.

Keynote: Emotions, al-Qur'an, Application, Education.

\section{Prolog}

Al-Qur'an pada berbagai ayat berbicara mengenai tabiat manusia $^{1}$ dan berbagai kondisi psikis serta penyakit yang dialaminya. $^{2}$ Emosi melatarbelakangi perbuatan dan kemauan manusia, yang akan menjadi penentu kualitas hidupnya. Emosi punya relasi kuat dengan seluruh kepribadian yang bisa mewarnai pada suasana hati. Membahas tentang emosi yang juga merupakan suatu hal tidak terlepas dari bingkai fisik dan psikologis yang cenderung bertindak pada setiap situasi dan kondisi, akan senantiasa mendorong manusia memunculkan untuk bertindak emosional. Dengan kata lain, bahwa emosi pada dasarnya adalah stimulus untuk bertindak, untuk merencanakan sewaktu-waktu dan untuk mencari solusi terhadap problem secara berangsur-angsur melalui proses evaluatif, ${ }^{3}$ dan dalam kehidupan sehari-hari dapat disaksikan tingkah laku dengan segala

\footnotetext{
${ }^{1}$ Al-Qur'an sebagai hudan (petunjuk) bagi manusia yang diharapkan adalah bagaimana dapat seoptimal mungkin mengamalkan maksud isi kandungan alQur'an dalam lini kehidupan sehari-hari, sehingga manusia memiliki karakter yang sesuai dengan nilai-nilai al-Qur'an. Moch. Yasyakur, Model Pembelajaran Karakter dalam Perspektif Al-Qur'an, (Jakarta: PTIQ, 2017), hlm. 1.

${ }^{2}$ Melalui al-Qur'an yang memerintahkan manusia untuk mengamati dirinya dan untuk menyucikannya. Baca Muhammad Izzuddin Taufiq, Panduan Lengkap dan Praktis: Psikologi Islam, Terj. Sari Nurlita dkk, (Jakarta: Gema Insani, 2006), hlm. 78.

${ }^{3}$ Daniel Goleman, Keccerdasan Emosional, Terj T. Hermaya, (Jakarta: Gramedia Pustaka Utama, 1996). hlm. 7.
} 
aktivitas atau kegiatan manusia, sesungguhnya merupakan tandatanda bahwa manusia adalah makhluk berjiwa.

Dapat dikakatan bahwa tidak akan ada muncul suatu tindak perbuatan manusia yang tidak dikendalikaan oleh emosinya. Emosi menjadi sentral saat seseorang menjelaskan perilaku atau perbuatannya $^{5}$ sehari-hari. ${ }^{6}$ Menurut informasi al-Qur'an terdapat banyak keterangan dan penjelasan tentang macaman emosi dasar yang dialami dan dirasakan manusia, diantaranya rasa takut, gembira atau senang.

Oleh karena banyak ayat al-Qur'an yang membincangkan tentang tabi'at manusia dan berbagai kondisi psikis, maka ayat-ayat ini menjadi pedoman bagi manusia untuk memahami realitas diri manusia, sifat-sifat dan kondisi psikis dalam usaha memperoleh gambaran yang benar tentang kepribadian dan motif dasar dalam mengarahkan jiwa dan tingkah lakunya. ${ }^{7}$ Oleh karenanya kecerdasan emosional $^{8}$ jauh lebih urgen daripada kecerdasan akademis dalam

\footnotetext{
${ }^{4}$ Ada tiga tahap yang digunakan ahli psikologi dalam membahas manusia. Pertama, manusia dipelajari sebagai sesuatu yang harus diamati secara ilmiah. Kedua, manusia dipelajari dari cara berfikirnya. Ketiga, manusia dipelajari dari dimensidimensi spiritualitas manusia sebagai psikologi transpersonal dan mendefenisikan pokok bahasannya sebagai bidang diri yang kekal dan tanpa batas, hal-hal mutlak yang membuka kesadaran, kebahagiaan, kesatuan dengan ketuhanan, pencerahan dan sebagainya. Harun Nasution, Islam ditinjau dari Berbagai Aspeknya, (Jakarta: UI Press, 2001), hlm. 30.

${ }^{5}$ Dapat dimaknai tingkah perilaku dalam pengertian psikologi pendidikan adalah segala kegiatan manusia yang tampak maupun tidak, disadari maupun tidak disadari. Termasuk dalam pengertian perilaku dalam hal ini adalah cara berbicara, berjalan, mengingat, cara bersikap, cara berreaksi terhadap sesuatu yang datang dari luar dirinya maupun dari dalam dirinya. Mahmud, Psikologi Pendidikan, (Bandung: Putaka setia, 2017), hlm. 14.

${ }^{6}$ Dengan munculnya kepribadian yang beraneka ragam pada diri manusia, dan dengan campuran yang relatif konsisten antara emosi, pikiran dan tingkah laku. Hal inilah yang kemudian menjadikan manusia menjadi makhluk yang unik. Dalam N. Fabes R.A. Eisenberg \& M. Reiser, Dispositional Emotionality and Rugulation: Their role in predicting quality of social functioning. Journal of Personality and Social Psychology, 78, 136-157.

${ }^{7}$ Rodiah dkk, Studi Al-Qur'an Metode dan Konsep, (Yogyakarta: ELSAQ Press, 2010), hlm. 297.

${ }^{8}$ Fungsi intelegensi dapat menaikkan kualitas dan nilai manusia ketingkat yang lebih tinggi. Namun intelegensi saja tidaklah cukup, malainkan harus diikuti dengan nurani yang tajam bersih. Nurani (mata batin, akal budi) atau sebagai nafsu muthmainnah (dorongan yang positif). Manusia bisa berkualitas kalau dia memiliki
} 
mengembangkan keperibadian yang utuh. ${ }^{9}$ Maka untuk mencetak manusia yang utuh seperti yang disampaikan oleh al-Qur'an, salah satunya dengan mendidik manusia mampu memahami amtsal yang disampaikannya, dan emosi juga sangat terkait dengan seluruh aspek kepribadian yang akan memberikan varian corak warna pada keadaan dan kondisi hati. Oleh karenanya mengatur emosi menjadi sesuatu yang urgen bagi perkembangan dan keberlangusungan kepribadian ${ }^{10}$ seseorang.

Demikian pula emosi gembira. Al-Qur'an menyebutkan kegembiraan mereka (mukmin) karena diturunkannya ayat-ayat alQur'an, yang mengindikasikan mereka kepada kebenaran, dan menjadi penyembuh dan rahmat bagi mereka. ${ }^{11}$ Emosi menjadi suatu sentral saat manusia menjelaskan perilaku atau perbuatan manusia sehari-hari, dan emosi terjalin pula erat dengan seluruh kepribadian $^{12}$ yang memberikan corak pada suasana hati, karena itu mengatur suasana hati menjadi sesuatu yang sangat penting bagi sebuah konstruk kepribadian qurani, yang pada gilirannya dapat memberikan implikasi pada dunia pendidikan Islam. ${ }^{13}$ Pendidikan merupakan kegiatan yang di dalamnya melibatkan banyak unsur dari manusia, diantaranya peserta didik (siswa), pendidik (guru) masyarakat dan orang tua. Oleh karena itu, agar tujuan pendidikan dapat tercapai secara efektif dan efisien, maka setiap orang yang

kebebasan untuk berbuat dan berkehendak. Umar Shihab, Kontekstualitas alQur'an, (Jakarta: Penamadani, 2005), hlm. 110.

${ }^{9}$ Hal ini logis dikarenakan sesungguhnya kontribusi "IQ" dalam mendominasi kesuksesan hidup maksimal sekitar 20 persen, sedangkan 80 persen sisanya ditentukan faktor-faktor penunjang lainnnya. Dalam Gordon Dryden dan Jeanette Vos, Revolusi Cara Belajar, (Bandung: Kaifa, 2001), hlm. 141.

${ }^{10}$ Kepribadian berasal dari bahasa Inggris yaitu personality, Belanda (personalita), Prancis (personalia), Jerman (personlichekesit), Italia (personalita), dan Spanyol (personalidad). Sedangkan akar katanya berasal dari bahasa latin yaitu personal yang berarti topeng, maksud topeng yang dipakai oleh aktor. Hamin Rosyidi, Psikologi Kepribadian I, (Surabaya: IAIN Sunan Ampel, 2010), hlm. 1.

${ }^{11}$ QS. Yunus, 10: 57-58.

${ }^{12}$ Kepribadian menurut psikologi diartikan sebagai suatu organisasi yang dinamis dari sistem psikofisik individu yang menentukan tingkah laku dan pola pemikiran individualistik secara khusus. Menurut Allport, sistem psikofisik di sini berarti jiwa raga. E. Koeswara, Teori-teori Kepribadian, (Bandung: Eresco, 1991), hlm. $10-11$.

${ }^{13}$ Tanpa makna maka seorang manusia tidak lagi menjadi manusia. Baca lebih lanjut dalam C. George Boeree, Personality Theories, Terj. Inyak Ridwan Muzir, (Jogjakarta: Prismashopie, 2004), hlm. 8. 
terlibat didalamnya harus bias saling memahami perilaku individu yang terkait. ${ }^{14}$ Dalam hal ini, psikologi pendidikan menjadi sangat urgen bagi para guru. Penguasaaan dan pengelolaan tentang psikologi dalam ranah pendidikan merupakan salah satu kompetensi pedagodik yang melekat pada dirinya.

\section{Pengertian Emosi}

"Emosi" berasal dari kata "emetus" atau "emouere" bermakna "to still up" yakni suatu dorongan terhadap sesuatu yang lain. ${ }^{15} \mathrm{Di}$ dalam Word College Dictionary, emosi adalah "setiap rangkaian kegiatan pikiran atau perasaan, nafsu serta setiap kondisi mental yang hebat atau meluap-luap." (emotions); adalah "reaksi subjektif terhadap pengalaman yang diasosiasikan dengan perubahan fisiologi dan tingkah laku". ${ }^{17}$ Sementara dalam Kamus Besar Bahasa Indonesia emosi ialah "berupa luapan perasaan yang berkembang dan akan surut dalam waktu singkat." ${ }^{18}$ Menurut para ahli psikologi bahwa emosi didefenisikan;

1. Jeane Segal mendefenisikan emosia adalah satu pengalaman seseorang yang bisa dirasakan secara fisikal. Artinya semua perbuatan yang diperbuat senantiasa mendapat respon baik ataupun tidak-baik secara fisik. ${ }^{19}$

2. Cronw yang dikutip oleh Usman Najati dan Juhaya S. Praja, memahami sesungghnya emosi bagian dari kondisi fisik yang bergejolak pada diri secara personal, ataupun diri dengan lingkungan dalam rangka mewujudkan kesejahterraan dan kenyamanan individual. ${ }^{20}$

3. Menurut Abin Syamsuddin Makmun, berpandangan sesungguhnya emosi itu didifenisikan sebagai sebuah suasana yang kompleksitas

\footnotetext{
${ }^{14}$ Mahmud, Psikologi Pendidikan, (Bandung: Pustaka Setia, 2017), hlm. 15.

${ }^{15}$ E. Usman Effendi dan Jyuhaya S. Praja, Pengantar Psikolougi, (Bandung: Angkassa, 1993), hlm. 79.

${ }^{16}$ Neufeld, Victoria, Webster's New Word College Dictionary, $3{ }^{\text {rd }}$ Eds, (New York : MacMillan References, 1999), hlm. 133.

${ }^{17}$ L.A. Bennett Sroufe, Emotinonal Devlopment Cambridge, (England: Cambridge University Press, 1997), hlm. 132.

${ }^{18}$ Departemen Pendidikan dan Kebudayaan, Kamus Besar Bahasa Indonesia (Jakarta: Balai Pustaka, 1994), hlm. 201.

${ }^{19}$ Sarlito Wirawan, Pengantar Umum Psikologi,..., hlm. 53.

${ }^{20}$ Jeane Segel, Meningkatkaen Kecerdasan Emosi (Jakarta: Citra Aksara, tt), hlm. 75 .
} 
(a complex feelingstate) dan adanya getaran jiwa (a stride up state) yang menyertai ataupun muncul sebelum atau seusai terjadi tindak perilaku. $^{21}$

Emosi ialah sesuatu yang berkorelasi dengan ekspresi fisik, atau perubahan-perubahan yang menyertai emosi. Sebagai ciri individu yang mudah meransang untuk mewujudkan tingkah laku emosional. Feelings ${ }^{22}$ atau perasaan merupakan pengalaman yang penuh dalam kesadaran, yang diaktifkan baik oleh perangsang eksternal maupun oleh macaman yang terjadi secara jasmaniah.

Salah satu keniscayan dalam kehidupan ialah fakta bahwa manusia mengalami berbagai peristiwa yang mengikutsertakan emosi. ${ }^{23}$ Penyebabnyapun beraneka ragam ada yang membahagiakan, menjengkelkan, menyeramkan, mengecewakan dan lainnya. Adapun dalam teori "law of effect" dari Thorndike menjelaskan hal ini. "Apabila sesuatu membuat seseorang senang, bahagia, atau puas, maka dia akan cenderung mengulanginya pada kesempatan lain. sebaliknya sesuatu yang menyebelkan atau menjijikkan cenderung dihindari". ${ }^{24}$

Lebih luas JS.Bruner mendefenisikan bahwa emosi berada pada kedalaman dua sisi pandangan yaitu; pertama, pandangan secara fisiologis, bahwa emosi sebagai proses jasmani dikarenakan perasaan yang meluap-luap. Kedua, sisi pandang dari psikologis, bahwa emosi merupakan reaksi feeling yang menggembirakan dan tidak menggembirakan baik bagi diri sendiri maupun orang lain. ${ }^{25}$

\footnotetext{
${ }^{21}$ Usman Effendi, Juhanna S. Praja, Pengantar Psikologi, (Bandung: Aksara, tth), hlm. 81 .

${ }^{22}$ Feeling merupakan pengalaman disadari, yang diaktifkan melalui bermacam rangsangan jasmani secara eksternal. J.P. Chaplin, Kamus Pssikologi, (Jakarta: Raja Grafindo Persada, 2009), hlm. 165.

${ }^{23}$ P.M. Bruschi \& B.L. Tamang mengatakan bahwa budaya dapat memengaruhi cara orang merasakan suatu situasi dan cara mereka menunjukkan emosi mereka. Misalkan budaya Asia, yang menekankan harmoni sosial, tidak mendukung ekspresi rasa marah, tetapi memproritaskan rasa malu. Namun hal sebaliknya berlaku pada budaya Amerika, yang menekankan pada ekspresi diri, pernyataan diri, dan harga diri. Dalam Diana E Papalia dkk, Human Development, (Jakarta: Salemba Humanika, 2009), hlm. 262.

${ }^{24}$ Dalam Al-Atapunnang, Manusia dan Emosi, (Maumere: Sekaolah Tinggi Filsafat Ledalero, 2000), hlm. 44.

${ }^{25}$ Pandangan Jhon Macquarie membagi emosi pada dua aspek yakni; Pertama, emosi negatif seperti rasa takut, rasa marah, rasa benci, rasa dengki dan cemas. Kedua; emosi positif (positive emotions) seperti rasa cinta (loving), rasa gembira (happiness). Psikolog mengklasifikasikan cakupan luas emosi dengan berbagai cara,
} 


\section{Pengertian Pendidikan}

Pendidikan dapat diartikan sebagai sebuah proses dengan metode-metode khusus sehingga orang memperoleh pengetahuan, pemahaman, dan cara bertingkah laku yang selaras dengan kebutuhan. Pengertian lain yang lebih representatif, pendidikan ialah "the total process off developing human abilities and behaviors, drawing on almost all life's experiences". artinya; "seluruh proses tahapan pengembangan kemampuan-kemampuan dan aneka perilaku manusia dan juga proses penggunaan di hampir seluruh pengalaman kehidupan." 26

Menurut Ramayulis hakikatnya belajar tersebut merupakan suatu proses atau perjalanan yang dilalui oleh individu untuk memperoleh perubahan secara tingkah laku mengarah lebih baik sebagai hasil dari pengalaman individu dalam berinteraksi dengan lingkungan sosial disekitarnya. ${ }^{27}$ Pemakaian istilah pengertian belajar juga menekankan pada proses atau kegiatan memperoleh dan hasilnya. Belajar adalah suatu aktifitas memperoleh pengetahuan, meningkatkan keterampilan, memperbaiki perilaku, sikap dan mengokohkan kepribadian. ${ }^{28}$

Sebagai metafora tentang ilmu jiwa pendidikan dari beberapa definisi tersebut, maka di sini dapat dipaparakan sebuah definisi dengan Ilmu jiwa pendidikan ialah: "ilmu pengetahuan yang menyelidiki gejala-gejala kejiwaan individu di dalam situasi pendidikkan". Bila disingkat, ilmu jiwa pendidikan ialah: "suatu ilmu

tetapi hampir semua klasifikasi merujuk sebuah emosi sebagai emosi positif atau emosi negatif. Emosi Positif mencakup antusiasme, kegembiraan dan cinta. Emosi negatif mencakup kecemasan, kemarahan, rasa bersalah dan kesedihan. Dalam L.F. Barret dkk, 2007, The experience of emotion, Annual Review of Psychology (Vol. 58). Palo Alto, CA: Annual Reviews.

${ }^{26}$ Abuddin Nata berpendapat bahwa proses belajar mengajar secara sederhana dapat diartikan sebagai kegiatan atau interaksi yang saling mempengaruhi antara pendidikdan peserta didik, dengan fungsi utama pendidik memberikan materi pelajaran atau sesuatu yang mempengaruhi murid. Sedangkan murid menerima pelajaran, pengaruh atau sesuatu yang diberikan oleh pendidik. Baca Abuddin Nata, Ilmu Pendidikan Islam, (Jakarta: Kencana, 2012), hlm.139.

${ }^{27}$ Perubahan tingkah lakudimaksud menurut Ramayulisdapat terjadi melslui mendemgar, membacs, mengikyti petunjuk, mengambil, menikirkan, mengahayati, meniru, melatih atau mencoba sendiri dengan pengajaran atau latihan. Dalam karyanya Ilmu Pendidikan Islam, (Jakarta: Kalam Mulia, 2013), hlm. 334.

${ }^{28}$ Suyono \& Hariyanto, Belajar dan Pembelajaran: Teori dan Konsep Dasar, (Bandung : PT Remaja Rosda Karya, 2012), hlm. 9. 
pengetahuan yang membincangkan seputar prilaku perorangan dalam situasi pendidikan". Dalam proses pendidikan, peserta didik menjadi salah satu komponen manusiawi yang menempati posisi sentral. Peserta didik menjadi asas persoalan dan pusat perhatian dalam semua proses transformasi yang disebut dengan pendidikan. Oleh karenanya sebagai satu komponen urgen dalam sistem pendidikan, peserta didik sering disebut sebagai "raw material" (bahan mentah). ${ }^{29}$

\section{Isyarat al-Qur'an Tentang Emosi Positif Manusia}

1. Emosi Takut

Di dalam al-Qur'an, kata takut digunakan dengan term "khauf" di dalam berbagai bentuknya terdapat di dalam 124 ayat. Sejumlah 18 ayat menggunakan bentuk fi'il madi (kata kerja masa lalu), 60 ayat dengan bentuk fiil mudari' (kata kerja masa kini), 34 ayat dengan bentuk masdar (infinitif), satu ayat dengan fi'l amr (kata kerja perintah), 8 ayat dengan bentuk fi'l al-nahyi (kata kerja larangan) dan tiga ayat dengan bentuk ism al-fá'il (kata pelaku).

Secara etimologi, kata "khauf" berarti "al-faza' (takut atau khawatir), ${ }^{30}$ al-qatl (pembunuhan), al-'ilm (pengetahuan), dan 'adimul ahmar (kulit merah yang disamak). Secara terminologi, khauf mempunyai arti "Kondisi (bisikan) kejiwaan yang timbul sebagai akibat dari dugaan akan munculnya sesuatu yang dibenci atau hilangnya sesuatu yang disenangi."

Al-Asfahāni menyatakan bahwa khauf adalah: " perkiraan akan terjadinya sesuatu yang dibenci karena pertanda yang diduga dan diyakini, sebagaimana harapan dan hasrat tinggi itu adalah perkiraan akan terjadinya sesuatu yang disenangi karena pertanda yang diduga atau diyakini, baik dalam urusan duniawi maupun ukhrawi."

\footnotetext{
${ }^{29}$ Desmita, Psikologi Perkembangan Peserta Didik, (Bandung: Remaja Rosdakarya, 2011), hlm. 39.

${ }^{30}$ Atabik Ali \& ahmad Zuhdi Muhdlor, Kamus Kontemporer Arab-Indonesia, .., hlm. 817.

${ }^{31} \mathrm{Al}$ Asfahani juga melihat ada dua istilah yang berkaitan dengan masalah di atas, yaitu al-Khauf minallah (takut kepada Allah) dan at-takhwif min allah (membuat seseorang takut akan Allah). Maksud yang pertama bukanlah berupa ketakutan kepada Allah yang tergetar dan terasa di dada manusia seperti takut kepada singa. Tetapi menahan dari dari perbuatan maksiat dan selanjutnya mengarahkannya utnuk tunduk dan patuh kepada Allah. Oleh karena itu, tidaklah disebut sebagai
} 
Bila ditelusuri dalam al-Qur'an aneka ragam emosi takut yang dilukiskannya, dimulai dari ekspresi menutup telinga disaat mendengar petir dan kilat yang menyambar, mengungsi ke luar negeri karena takut perang, sampai ketakutan pada dirisendiri, oranglain, dan Tuhan. ${ }^{32}$ Rincian macam-macam ayat tersebut digambarkan sebagai berikut; Pesan Allah swt pada Q.S. al-Baqarah (2): 19. Surat al-Isrā' (17): 109. Dan pada Surat al Baqarah (2 ): 243.

Emosi takut akan dibarengi banyak perubahan pada fungsi fisiologis yang tersumbat, raut wajah berubah, nada suara sampai kepada keadaan fisik. Manusia merespons keadaan bahaya yang mengancamnya dan emosi takut dengan bergerak menjauh dan lari dari bahaya tersebut. Al-Qur'an telah mendeskripsikan respons manusia tersebut berupa lari dari berbagai keadaan bahaya yang mengancam serta bangkitnya takut. Hal tersebut diungkapkan saat menggambarkan al-käfirin dan umat terdahulu yang telah ditimpa azab Allah swt., lantaran mereka mendustakan para nabi mereka dan bersikukuh dalam kekafiran. Mereka diliputi kepanikan seraya bergegas lari menjauh dari azab Allah swt.

a. Emosi Takut terkait dengan diri sendiri.

Di dalam al-Qur'an ada rangkaian ayat-ayat yang menjelaskan ketakutan pada diri sendiri yang selalu timbul setiap kali mengingat suatu peristiwa tertentu di masa lampau. Pada Surat al-Shu'arā'/26: 14. Dan pada Surat al Qașaș/28: 18, Surat Ali Imrān/3: 151 dan pada Surat al-Rūm/30 : $28 .^{33}$

Kutipan dua ayat pertama (surat al-Shu'arā'/26:14 dan al Qașaș/28:18) ${ }^{34}$ menerangkkan bahwa emosi takut pernah dirasakan Nabi Musa as. setelah tanpa adanya unsur kesenggajaaan membunuh seorang pemuda. ${ }^{35}$

seorang takut, bila belum sanggup menghilangkan perbuatan-perbuatan dosa. Sedangkan yang kedua adalah perintah agar tetap melaksanakan dan memelihara kepatuhan kepada-Nya, seperti firman Allah dalam QS. Al-Zumar (39): 16. AlRaghib Al Ashfahānì, Mu'jam Mufradat al Faz al Qur'ān, (Beirut : Dār al Fikr, 1432H), hlm. 122.

${ }^{32}$ Istilah ketakutan pada diri sendiri disebut (intrapersonal), pada orang lain dengan istilah (interpersonal), dan ketakutan pada Tuhan disebut dengan (metapersonal). Darwis Hude, Emosi, Penjelajahan Religio-Psikologis,...., hlm. 194.

${ }^{33}$ lihat selanjutnya pada ayat $19,20,21$, dan 33 .

${ }^{34}$ Pada surat al-Shu'arā' (26): 14. Juga terdapat pada surat al-Qașaṣ (28): 18.

${ }^{35}$ Al-Biqā'i sebagaimana dikutip oleh M. Shihab memahami ucapan nabi Musa as.yang berkata "inni $\bar{i}$ akhäfü" pada ayat diatas sebagai keluhan yang dicelahnya 
b. Emosi Takut terkait hubungan dengan orang lain

Emosi takut yang juga sering dijumpai adalah rasa ketakutan karena terjadi konflik, apakah itu terjadi konflik antara individu, antar-kelompok, maupun individu dengan kelompok. Al-Qur'an merekam berbagai peristiwa menyangkut emosi takut pada ketiga model hubungan terkait dengan orang lain.

1). Emosi takut (hubungan individu dengan individu) terdapat pada Surat Țāhä/20: 67-68. danSurat al-Shu'arā'/26:21.

2). Emosi takut (terkait individu dengan kelompok), terdapat pada Surat $\mathrm{S}$ ād/38 : 22. Dan pada Surat Țāhā/20 : 44-46. Dan Surat Ṭāhā/ $20: 77$.

3). Emosi Takut (hubungan kelompok dengan kelompok), hal tersebut terdapat pada Surat 4: 77., Surat 4: 101. Surat 10: 83.

Dan pada surat $5: 21-23$ sebagaimana tertera di bawah ini;

Penjelasan dari ayat-ayat yang dikutip di atas tampak dengan terang benerang terwudjudnya kesan ketakutan terhadap manusia, dalam hal ini, penjelasan ini adalah penguasa yang zhalim, kelompok tirani yang perkasa (qaum jabbärin), dan para serdadu yang menjadi mesin perang. Akan tetapi, Allah swt., kemudian memberi penguatan kepada kaum mukminin untuk tidak takut menumpas kebathilan dan menegakkan sesuatu yang benar dan haq.

c. Emosi Takut terkait dengan Tuhan

Al-Qur'an memandang manusia sebagai salah satu dari sekian banyak makhluk ciptaan Allah swt., yang dinobatkan sebagai khalifah di bumi. Ada dua hal yang harus selalu diperhatikan manusia dalam mengemban tugas mulia ini. Pertama, membina relasi harmonis antar ummat manusia dan lingkungan hidupnya sekitarnya (relasi bersifat horisontal sesama makhluk). Kedua, membina hubungan vertikal dengan al-Khäliq (Tuhan). Tanpa kedua hal

mengandung permohonan kepada Allah swt. Menurutnya, nabi Musa as. Bagaikan berkata; "Aku takut mereka mendustakanku, sehingga kedatanganku kepada mereka tidak bermanfaat, dan mereke akan berusaha mencelakakanku, maka karena itu anugerahilah aku wibawa yang dapat memeliharaku dari siapapun yang bermaksud buruk." Al-Biqā'i juga memungkinkan kata "akhaf" bukan dalam arti takut tetapi mengetahui atau menduga. Agaknya ini yang dikemukakan oleh penafsir itu karena enggan menerima adanya kesan bahwa Nabi Musa as. Ketika itu merasa takut. Sebenarnya kesan tersebut tidak perlu terlalu dikhawatirkan, karena perasaan takut adalah naluri manusia, dan para rasul memiliki naluri yang sama dengan semua manusia lainnya. M. Quraish Shihab, Tafsir al Misbah, Pesan, Kesan dan Keserasian al-Qur'an, (Jakarta: Lintera Hati, 2002), Vol. 10. hlm. 16. 
tersebut, maka derajat manusia akan turun menjadi makhluk hina (3:112).

Ada dua term yang sering diketengahkan, yaitu: al-khauf dan al-khash-yah, selain term taqwa yang selalu diartikuluasikan kedalam bahasa Indonesia dengan makna 'takut' yang sesungguhnya kurang tepat. Namun sebagian mufassir memproposisikan kedua term itu (al-khauf dan al-khash-yah), namun mufassir lain mengelompokkannya kepada sinonim saja. Ayat-ayat yang menggunakan term khashiya antara lain (lihat juga surat 21:28; $23: 57 ; 24: 52 ; 33: 39 ; 50: 32-34 ; 59: 21 ; 79: 8-9,26 ; 80: 8-10 ; 87: 10$; 98:8): Surat Yāsin/36 : 11, dan Surat al-Mulk/ 67 : 12. Sementara ayat-ayat yang menggunakan term khäfa antara lain (lihat juga surat $5: 28 ; 3: 175 ; 6: 51 ; 7: 56 ; 13: 13 ; 55: 46 ; 59: 16 ; 72: 13)$ : Juga pada Surat Ibrāhim/14 : 14, dan Surat al-Sajadah/32 : 16 .

Terdapat pula ayat yang menggunakan term khashiya dan khafa sekaligus, yaitu surat al-Ra'd/ 13:21. Ayat terakhir ini menjadi penguat terhadap pembedaan antara term khashiya dan khafa di atas. Intensitas takut lebih mendalam pada term khashiya bila dibanding dengan term khafa. Emosi takut kepada Allah yang muncul pada perilaku setan, seperti tersebut dalam surat al Hashr/59:16, berbeda dengan ekspresi takut pada manusia yang beriman. Karena itu, ungkapan takut kepada Allah dari setan tidak menggunakan term khashiya, tetapi khafa (al Harsy/59:16, misalnya dengan alBaiyyinah/98:8).

d. Emosi takut terhadap musibah dan bencana

Musibah atau bencana adalah bagian dari sebuah realita kehidupan, ia datang tanpa diundang, dan pergi sesuka hati. ${ }^{36}$ Banyak hal yang menjadi penyebab terjadinya suatu bencana. Tapi, setidaknya tak pernah lepas dari dua hal: faktor manusia (misalnya banjir akibat penebangan hutan) dan alam (gempa bumi, angin topan, dll). Sesuai dengan naluriah, manusia memiliki rasa takut terhadap segala bentuk bencanas. Ketakutan inilahyang kemudian harus disadari sebagai anugerah Allah swt. yang dibutuhkan mannusia agar dapat menyelamatkan kelangsungan hidupnya dari kepunahan.

\footnotetext{
${ }^{36}$ Terkait dengan bencana dan musibah, ada beberapa istilah yang digunakan alQuran untuk menunjuk sesuatu yang tidak disenangi, antara lain 'musibah, bala', 'azab, 'iqab dan fitnah. Pengertian dan cakupan maknanya berbeda-beda. Baca lebih lanjut M. Quraish Shihab, Jurnal Studi al Quran, Vol. 1. Musibah dalam Perspektif al-Quran, (Jakarta: PSQ, 2006), hlm. 5.
} 
Emosi takut pada bencana yang seringkali disinggung oleh AlQur'an ialah berkaitan dengan bencana pada hari akhirat, sedangkan selainnya hanya dijelaskan dalam beberapa ayat saja. Hal tersebut diatas terdapat pada Surat al An'̄m/6:15. ${ }^{37}$, Surat al Isrā'/17: 31. Dan pada Surat Maryam/19: $5^{38}$

\section{Emosi Gembira}

Kata gembira atau senang al-Qur'an menampilkannya dengan term 'farihin' yang terambil dari akar kata faraha pada mulanya berarti "senang". ${ }^{39}$ Dari sini arti kata tersebut berkembang; misalnya suatu perbuatan yang direstui dinamakan al farh karena yang direstui itu adalah juga perbuatan yang disenangi, seperti diisyaratkan hadis nabi yang diriwayatkan oleh at Tabarani " Allah lebih senang dengan taubat hambanya”. Orang yang merasa kesulitan membayar utangnya karena ia tidak mendapatkan sesuatu untuk pembayarnya disebut mufrah. Disebut demikian karena keadaaan yang dihadapinya memberi kelonggaran baginya untuk membayarnya setelah mampu dan kelonggaran itu mengantar di kepada kesenangan.

Kata 'faraha' dengan berbagai bentukanya lebih banyak digunakan al-Qur' an untuk mengambarkan kesenangan duniawi yang timbul karena materi dan cendrung bersifat negatif, seperti merasa sombong karena kekayaan. Sementara kata farihin termasuk yang selalu digunakan untuk arti kesenangan dunia yang bersifat negatif, sedangkan yang menunjuk kepada kesenangan di akhirat hanya disebut sekali yaitu pada surat Ali Imran (3): 170.

\footnotetext{
${ }^{37}$ Lihat pula surat $7: 59 ; 10: 15 ; 11: 3,26,84,103 ; 17: 57 ; 24-37,50 ; 26: 135 ; 39: 13$; $46: 21 ; 51: 37 ; 52: 26-27 ; 70: 27-28 ; 76: 7,10)$.

${ }^{38}$ Kekahawatiran Nabi Zakariya dalam salah satu muqaddimah dia bermunajaat pada Tuhan adalah beliau mengajukan alasan mengapa berliau bermohon anak bukan selainnya, yakni karena merasa khawatir mengahdap masa depan. Di sisi lain, beliau juga sadar bahwa permohonan itu jika diukur dengan kebiasaan dan logika manusia, ia adalah sesuatu yang sangat jauh untuk dapat diaraih. Ini dicerminkan oleh pengakuannya bahwa istrinya mandul sejak dahulu (masa muda). Sebagaimana dipahami dari kata "kānat" yang digunakan melukiskan keadaan istrinya itu. Namun demikian ia tidak berputus asa dari rahmat ilahi, bahwa Allah kuasa mewujudkannya dengan cara-cara yang tidak terjangkau oleh nalar manusia. M. Quraish Shihab, Tafsir al Misbah, Pesan, Kesan dan Keserasian al-Qur'an, (Jakarta: Lintera Hati, 2002), Vol. 7. hlm.hlm. 441.

${ }^{39}$ Atabik Ali \& ahmad Zuhdi Muhdlor, Kamus Kontemporer Arab-Indonesia,.., hlm. 1383.
} 
Menurut Ar Raghib al-Ashfahani, dari sekian banyak kata faraha dan yang seakar dengannya, hanya dua kali disebut oleh al Quran yang menunjuk kesenangan dunia yang bersifat positif, yaitu di dalam QS. Yunus (10): 58 dan QS. Ar Rum (30): $4{ }^{40}$ Kondisi emosi gembira atau senang dalam al-Qur'an juga dapat dipaparkan dalam aneka klasifikasi sebagai berikut;

a. Gembira memperoleh nikmat atau lepas dari kesulitan

Ayat al-Qur'an yang berkonotasi dengan masalah ini memang tidak secara langsung menyebut faktor kenikmatan dan kesulitan tersebut. Dengan demikian, dapat dipahami bahwa ukuran kenikmatan dan kesulitan juga bersifat subyektif. Pemaparan alQur'an tentang emosi senang terhadap kenikmatan yang diraih, atau karena terbebas dari kesulitan dapat dilihat pada ayat-ayat berikut ini yakni pada Surat $11: 10$, Surat $30: 36$, dan Surat $3: 170$, Surat 10 : 58 , juga terdapat pada Surat $12: 33-34$ sebagi berikiut;

Sedangkan nikmat dan rahmat yang dapat melahirkan kesenangan, adalah kesehatan, keamanan dan perlindungan, serta kelapangan rezeki. ${ }^{41}$ Kata 'adzaga' (membuat dia merasa) hanya dipakai untuk hal ikhwal yang membawa kenikmatan, dan tidak untuk hal ikhwal yang mendatangkan kesulitan. Ketiga ayat pertama $(11: 10,30: 36,42: 48)$.

Sedangkan surat 12:33-34 menceritakan kesenangan Yūsuf yang terbebas dari jerat-jerat cinta isteri majikannya, meskipun ia harus memilih penjara peristirahatannya. Penjara baginya lebih aman daripada istana atau tempat lain yang penuh dengan buaian-buaian asmara. Walaupun ada beberapa ulama memahami ucapan Yusuf as. yang terangkum pada ayat diatas sebagai doa. Bahkan ada yang berkata seandainya dia tidak menyebut kata "lebih suka dipenjara"

\footnotetext{
${ }^{40}$ Dengan menerapkan pengertian dan penggunaan kata di atas, terlihat perbedaan kata itu dengan kata mata' yang berarti juga "kesenangan". Kesenangan yang terdapat di dalam kata "farah" mempunyai aksentuasi duniawi dan ukhrawi. Sedangkan kata mata' hanya mempunyai aksentuasi kesenangan duniawi semata, tidak pernah digunakan untuk kesenangan ukhrawi. Tim Penyusun, Ensiklopedia al Quran, Jilid 1, (Jakarta: Lentera Hati, 2007). hlm. 217.

${ }^{41} \mathrm{Abu}$ al-Barakāt 'Abd Allah ibn Ahmad ibn Mahmud al-Nasafi, Tafsïr al-Qur'ān al-Jalil, (Beirut: al-Amawiyyah, t.t.) Jld. II, hlm.147. Lihat juga Abu al-Sa'id Muhammad ibn Muhammad al-'Imadi, Irshād al-'Aql al-Salim ilā Mazāyā alQur'ān al-Karìm, (Beirut : Dār Ihya' al-Turāth al-‘Arabì, t.t.), Jld. IV, hlm. 189.
} 
niscaya dia tidak akan dipenjara. Dan karena itu kata meraka, hendaknya sesorang tidak bermohon kecuali yang baik. ${ }^{42}$

b. Gembira terhadap kesusahan orang lain

Lazimnya, manusia akan merasa gembira setelah terbebas dari berbagai problematika yang menjeratnya. Terdapat dalam alQur'anyang mensinyalir adanya orang-orang tertentu yang merasa senang dan bangga melihat kesulitan orang lain. Setiap kali melihat musibah, seketika itu pula ia merasakan kegembiraan dan kepuasan pada dirinya, meskipun dalam banyak kasus tidak ditampakkan. Sebaliknya, jika orang lain sukses, ia sedih dan iri hati. Al-Qur'an menyentil masalah ini pada dua ayat, masing-masing di surat 3: $120 .^{43}$

Pasa ayat tersebut diatas dijelaskan bahwa adanya unsur emosi gembira dan senang ketika melihat orang lain mendapat kesulitan, pada hakikatnya merupakan suatupenyelewengan dari sisi fitrah kemanusiaan. Secaraumumnya hal itu didasari oleh faktor irihati dan denda mmendarah daging. ${ }^{44}$ Ajaran Islam datang untuk menghilangkan sifat-sifat seperti itu dengan mendorong manusia untuk selalu memberi manfa'at kepada sesamanya $(4: 54 ; 7: 43 ; 15: 47$; 28:77; 113:5). Dalam kajian psikologi, attitude senang memberi bantuan kepada orang lain disebut altruisme. Sikap ini senantiasa diharapkan menjadi sikap hidup bagi setiap lini kehidupan orang Muslim.

c. Senang terhadap lawan Jenis

Ketertarikan pada lawan jenis adalah karunia Allah untuk kelestarian spesies manusia. Ia merupakan salah satu drive (dorongan) yang bersifat alami pada manusia, muncul sangat kuat ketika alat-alat reproduksi mencapai kematangannya (sexual maturation). Islam telah mengatur penyaluran dorongan itu melalui lembaga pernikahan agar manusia tidak merendahkan martabatnya sendiri setara dengan binatang. Ketertarikan terhadap lawan jenis

\footnotetext{
${ }^{42}$ M. Quraish Shihab, Tafsir al Misbah, Pesan, Kesan dan Keserasian al-Qur'an, (Jakarta: Lintera Hati, 2002), Vol. 6. hlm. 81.

${ }^{43}$ Pasa ayat tersebut diterangkan bahwa emosi gembira dan senang ketika melihat orang lain mendapat kesulitan, pada hakikatnya merupakan suatu penyimpangan dari nilai fitrah kemanusiaan. Hal ini sebabkan didasari oleh faktor iri hati dan dendam yang bersarang dihati.

${ }^{44}$ M. Darwis Hude, Tentang Emosi Manusia, Ibid,..., hlm.184.
} 
dijelaskan oleh al-Qur'an dalam beberapa ayat dan Surat 3: 14. Dan pada Surat 30: 21, sebagai berikut;

Rangkaian pada ayat 30-32 dari surat ke-12 di atas menggambarkan emosi senang (cinta) terhadap lawan jenis dengan keterbangkitan emosi yang mendalam. Emosi cinta isteri seorang perdana menteri, kepada anak angkatnya yang tertolak memancing gosip di seluruh negeri. Dikisahkan lebih lanjut bahwa ekspresi emosi cinta dari para; wanita terhormat terhadap Yusuf yang sengaja diundangnya muncul dalam bentuk kekaguman (dengan komentar: melebihi wajah pria manapun, bahkan difantasikan sebagai malaikat) dan tak terasa jari-jari tangan mereka terluka karenanya.

Al-Qur'an juga mensinyalir adanya penyimpangan ketertarikan manusia pada sesama jenis (khususnya laki dengan laki atau homo seksual), sebagaimana terjadi di zaman Nabi Luth (7:81; $27: 55 ; 29: 29)$. Bahkan, fenomena itu kini tidak hanya menggejala, tapi juga mewabah, khususnya pada masyarakat Barat. Tak terhitung banyaknya penyimpangan seksual di masyarakat, tetapi AlQur'an telah menetapkan normalitas seks hanya pada lawan jenis (23:5-7).

d. Senang terhadap Harta

Manusia pada umumnya senang kepada harta kekayaan merupakan bentuk kesenangan lain yang didambakan manusia, kecuali mereka yang mempraktikkan zuhd (membatasi diri terhadap kenikmatan duniawi). Sementara ayat-ayat lain Al-Qur'an yang membincangkan tentang kesenangan manusia kepada harta kekayaan, diantaranya tertera padaSurat $89: 20$, pada Surat 100: 8, dan dalam Surat $18: 34$, termasuk pada Surat 13: 26.

Ayat terakhir ini memang tidak tegas menyatakan kesenangan kepada harta benda, tetapi secara umum disebutkan senang pada kehidupan dunia (al-hayat al-dunyawiyah). Salah satu bentuk kesenangan duniawi yang paling diminati manusia adalah pada harta benda, sehingga al-Qur'an menyebutkan bahwa kehidupan duniawi antara lain adalah kebanggaan pada harta benda (57:20). Kebanggaan kepada harta kekayaan biasanya dipamerkan atau diceritakan sebagai simbol status sosial, seperti dinyatakan surat 18:34 di atas.

e. Senang memberi atau menerima

Ada sebagian orang yang senang dan gembira jika mampu memberi sesuatu kepada orang lain, tetapi kebanyakan lebih senang jika dapat menerima. Orang yang suka memberi akan merasa puas 
ketika ia sanggup mengulurkan bantuan buat orang lain. Ada kepuasan batin jika sanggup menolong orang yang sedang tertimpa kesulitan, meskipun hal itu akan mengurangi apa yang dia miliki. ${ }^{4}$

Sifat senang memberi atau menerima ini terekam dengan jelas dalam Al-Qur'an. Ada jenis pemberian yang dimotivasi oleh keikhlasan dan ada pula yang disertai pemberian rasa pamrih. Menerimapun demikian, ada yang menggerutu ketika tidak mendapatkan apa yang diharapkannya. Berikut ini sebagian ayat yang berbicara tentang hal-hal tersebut, seperti yang termaktub pada Surat 59: 9, Surat 27: 36, Surat 9: 58-59, dan Surat 4: 4.

f. Senang pada hasil usaha-prestasi

Prestasi merupakan suatu hal yang diupayakan untuk dicapai oleh manusia; selalu ada prestasi yang diperjuangkan dalam segala aspek kehidupan ini. Karena itu, orang biasanya akan merasa gembira apabila prestasi yang diharapkannya menjadi kenyataan. Pencapaian sebuah prestasi umumnya membangkitkan perasaan bahagia. Tidak jarang kita jumpai orang meneteskan air mata haru karena prestasi yang telah sekian lama diperjuangkannya berhasil diraih dengan sempurna. Apakah prestasi di bidang pekerjaan, musabaqah alQur'an, olah raga, musik, maupun prestasi lainnya dalam kehidupan, semuanya dapat memberi kepuasan. Al-Qur' an mensenyalir beberapa luapan kegembiraan berkat tercapainya sebuah prestasi, terlepas apakah prestasi tersebut baik atau buruk menurut perspektif ajaran agama. Hal ini terekam dalam al-Qur'an pada Surat 30: 2-4 dan Surat 16: 97. Surat 6: 135 , surat 3: 188, surat 40: 83.

\section{Aplikasi Emosi Dasar yang Positif Pada Pendidikan}

1. Pengembangan Emosi Positif bagi Guru dan Murid

Pengeloloaan emosi sangat urgen dalam setiap lini kehidupan manusia, terkhusus untuk memproteksi ketegangan yang muncul sebagai efek emosi yang memuncak. Terwujudnya emosi dapat

\footnotetext{
${ }^{45}$ Hadis Rasulullah memberi apresiasi terhadap orangyang gemarmemberi daripada menerima: artinya: "Sedekah terbaik adalah yang diberikan orang kaya. Memberi itu lebih baik daripada menerima, dan mulailah memberi kepada orangyang menjadi tanggunganmu." Hadits Riwayat Muslim:1716; Bukhari:1338' 1379, 2545, 2910, 5960; Turmuzhì:2387; al-Nasā'î:2484, 2496, 1554-6; Ahmad: 14778, 14787, 15022; al-Dārimī:1591, 1594, 2632).
} 
menjadi sebab labilitas hormonal di dalam tubuh, dan menampilkan ketegangan psikis, teristimewa pada emosi-emosi negatif. ${ }^{46}$

Dalam ranah proses pembelajaran, karena belajar yang berkonotasi pada aktivitas siswa, sedangkan aktivitas individu dapat dipengaruhi oleh kondisi emosional, maka sepantasnya suasana pembelajaran yang kondusif dalam keadaan nyaman dan menyenangkan, inilah tugas seorang guru sebagai pendidik. Dengan suasana yang kondusif maka muncullah motivasi dan kreativitas, kondisi inilah cikal bakal aktivitas belajar dengan indikator tersebut di atas. Hal ini sesuai dengan istilah pembelajaran dengan prinsip Pakem, yaitu pembelajaran aktif, kreatif, dan menyenangkan. ${ }^{47}$

Manusia diberikan kemampuan untuk bisa berfikir, ${ }^{48}$ berbahasa, kesadaran, emosi, perilaku dan keperibadian lewat satu organ yang unik dan dahsyat yaitu otak. Otak menjadi satu tumpuan bagi perasaan dan perilaku. Otak mencerminkan dunia manusia. Otak tersebutlah yang menerima dan mengalami peristiwa. Segala sesuatu yang berawal dan berakhir di otak. Cara kerja otak menentukan kualitas hidup manusia. Kondisi fisik otak sebenarnya berdampak besar terhadap pola pikir, perasaan dan perilaku dari waktu kewaktu. ${ }^{49}$

Dalam persfektif pedagodis, peserta didik diartikan sebagai sejenis makhluk "homo educandum", mahkluk yang menghajatkan pendidikan. ${ }^{50}$ Dalam pengertian ini, peserta didik dipandang sebagai manusia yang memiliki potensi yang bersifat laten, sehingga dibutuhkan binaan dan bimbingan untuk mengaktualisasikannya agar dapat menjadi manusia susila yang cakap. Dalam persfektif psikologis menurut Arifin, peserta didik adalah individu yang sedang berada dalam proses pertumbuhan dan perkembangan, baik fisik maupun psikis menurut ftrahnya masing masing. Sebagai individu yang tengah tumbuh dan berkembang, peserta didik memerlukan

\footnotetext{
${ }^{46}$ Bimo Walgito, Pengantar Psikologi Umum, (Yogyakarta: Andi, 2010), hlm. 222. ${ }^{47}$ De Porter, Bobbi. Quantum Learning. (New York: Dell Publishing, 1992).

${ }^{48}$ Baca Sumardi Suryabrata, Psikologi Pendidikan, (Jakarta : Raja Grafindo Persada, 2006), hlm. 105-106.

${ }^{49}$ Baca lebih lanjut dalam Musa Asy'arie Taufiq Pasiak, Tuhan Empirik dan Kesehatan Spritual, (Yogyakarta : C-NET, 2012), hlm. 153-159.

${ }^{50}$ Desmita, Psikologi Perkembangan Peserta Didik, (Bandung: Remaja Rosdakarya, 2011), hlm. 39.
} 
bimbingan dan pengarahan yang konsisten menuju ke arah titik optimal kemampuan fitrahnya. ${ }^{51}$

Dari beberapa penjelasan peserta didik di atas, jelaslah bahwa peserta didik memiliki beberpa karakteristik; pertama: peserta didik adalah individu yang memilkiki potensi fisik dan fisikis yang khas, sehingga menjadikan dirinya sebagai manusia yang unik. Oleh karena itu potensi tadi perlu dikembangkan dan diterjemahkan sehingga mampu mencapai taraf perkembangan yang optimal. Kedua: peserta didik adalah individu yang dianggap sedang berkembang. Ketiga: peserta didik dalah sosok individu yang membutuhkan bimbingan individual dan perlakuan manusiawi, maka dengan demikian proses pemberian bantuan dan bimbingan harus mengacu kepada level perkembangannya pula.

2. Emosi positif Manusia dalam Pembelajaran

Pendidikan secara sederhana bisa dimaknai sebagai suatu prosses dalam rangka mempengaruhi peserta didik atau murid agar dapat menyelaraskan diri dengan sebaik mungkin terhadap lingkungannya, dengan demikian akan memunculkan perkembangan perubahan dalam dirinya yang memungkinkannya berperan secara baik dalam lingkungan kehidupan bermasyarakat di sekolah.

Emosi sangat memberi pengaruh besar pada kualitas dan kuantitas hidup manusia. Emosi positif dapat mempercepat proses belajar dan mencapai hasil belajar dengan baik, sebaliknya emosi yang negatif dapat menekan lajunya waktu belajar atau bahkan menghentikannya sama sekali. Oleh sebab itu, pembelajaran yang berhasil haruslah dimulai dengan menciptakan emosi positif pada diri pembelajaran. Dalam menciptakan emosi positif pada diri siswa dapat diusahakkan melalui berbagai cara, diantaranya ialah; dengan menciptakan lingkungan belajar yang menyenangkan dan penciptaan kegembiraan belajar. ${ }^{52}$

\footnotetext{
${ }^{51}$ Desmita, Psikologi Perkembangan Peserta Didik,..., hlm. 40.

${ }^{52}$ Dalam hal ini M. Arifin dalam Baharuddin mengatakan bahwasanya salah satu faktor pendukung yang menentukan dalam proses belajar mengajar di dalam kelas adalah guru. Oleh karena itu, guru tidak saja mendidik fungsi sebagai orang dewasa yang bertugas frofesional memindahkan ilmu penegetahuan (tranfer of knowladge) atau penyalur ilmu pengetahuan (tansmitter of knowledge) yang dikuasai pada anak didik, tetapi lebih dari itu. Guru menjadi pemimpin atau menjadi pendidik dan pembimbing dai kalangan anak didik. Baharuddin, Pendidikan dan Psikologi Perkembangan, (Yogjakarta: Ar Ruzz Media, 2010), hlm. 195.
} 
Kegembiraan belajar acap sekali menjadi penentu utama kualitas dan kuantitas belajar. Kegembiraan dan rasa senang bukan berarti menciptakan suasana kelas yang tidak nyaman dan penuh canda ria. Akan tetapi suasana kegembiraan bangkitnya pemahaman dan aneka nilai sikap positif yang membahagiakan pada diri pelajar. Selain itu juga dapat dilakukan pengembangan kecerdasan emosional peserta didik. Dalam mewujudkan kemampuan mengelola emosi secara sehat dalam membangun relasi dengan orang lain. Peserta didik yang emosinya tidak stabil akan menghambat kelancaran belajarnya. Dengan suasana yang kondusif maka muncullah motivasi dan kreativitas, kondisi inilah cikal bakal aktivitas belajar dengan indikator tersebut di atas. Hal ini sesuai dengan istilah pembelajaran dengan prinsip Paikem, yaitu pembelajaran aktif, kreatif, dan menyenangkan.

Rasulullah saw bersabda;

$$
\text { يسروا ولا تعسرو ,وبشرواو لا تنفروا }
$$

"Mudahkanlah dan jangan dibuat susah, senangkanlah dan jangan membuat kecewa."

Dengan demikian akan tumbuh pribadi positif, yaitu optimis, ada keinginan untuk memperbaiki diri, mengendalikan situasi, punya kebebasan memilih alternatif, partisipatif, rendah hati, pemaaf, dan tanggung jawab. Hindari prilaku dan komunikasi negatif yaitu marah, berbohong, ragu, cemas, takut, dan sifat negatif lainnya. Maka dapat dikatakan emosi secara umum dapat memberi athar (pengaruh) keberhasilan dalam belajar dan pencapain pengukiran prestasi. Emosi yang positif dapat mempercepat proses belajar dan menggapai hasil belajar yang lebih baik.

Para psikolog menganjurkan agar peserta didik sebaiknya diperlakukan secara objektif dan jangan sampai membandingkan antara satu anak-anak yang lain, juga menyarankan agar memberikan perhatian dengan penuh kasih sayang sebagai salah satu faktor penting dalam perkembangan emosi anak selanjutnya. ${ }^{53}$

Belajar merupakan proses dari perkembangan hidup manusia. dengan belajar manusia melakukan perubahan-perubahan kualitatif individu sehingga tingkah lakunya berkembang. Semua aktivitas dan prestasi hidup manusia tidak lain adalah hasil dari belajar. Belajar bukan sekedar pengalaman, belajar ialah suatu prosess dan bukan

\footnotetext{
${ }^{53}$ Djaali, Psikologi Pendidikan, (Bandung: Bumi Aksara, 2012), hlm. 43.
} 
suatu hasil, karena itu belajar berlangsung secara efektif dan integratif dengan menggunakan berbagai bentuk perbuatan untuk mencapai suatu tujuan. Proses belajar berbeda dengan proses kematangan, kematangan adalah proses dimana tingkah laku dan sikap $^{54}$ yang dapat dimodifikasi sebagai akibat dari pertumbuhan dan perkembangan struktur serta fungsi-fungsi jasmani.

Belajar pula menjadikan sebuah usaha untuk membentuk tanggapan-tanggapan baru. Pendapat ini dikemukakn oleh psikologi asosiasi, peristiwa belajar dipandangnya sebagai peristiwa untuk menghadapi masalah-masalah berdasarkan pada masalah yang telah ada. Dalam belajar ada proses mental yang aktif, semakin lama belajar maka semakin munculnya stimulus yang dapat membantu sehingga dengan natural kesalahan-kesalahan semakin lama semakin berkurang, kendatipun dalam prosesnya makin teratur, keraguan makin hilang dan timbul ketetapan. ${ }^{55}$

Di dalam al-Qur'an berulang kali mensenyalir manusia diangkat posisi derajatnya, namun berulang kali pula manusia dihinadinakan. ${ }^{56}$ Itu terjadi karena manusia disamping diberikan fisik yang sempurna dan indah ia pun di beri akal untuk berfikir, fitrah untuk menyembuh dan nafsu untuk mencapai keinginan. Melalui potensi yang dimiliki itu pulalah ia dihargai sebagai mahkluk yang mampu menaklukkan alam. Mutahhari menegaskan, "mereka juga merosot menjadi yang paling rendah dari segala yang rendah", karena ketidak berdayaannya untuk memfungsikan potensi tersebut sesuai dengan hakikat penciptaan manusia". 57

Dalam lingkup pendidikan, termasuk proses pembelajaran pendidikan agama Islam, memahami atau membaca aneka hal yang tampak pada (fisik atau jasmaniyah) dan tidak tampak (psikis atau ruhaniyyah) sangat urgen, ${ }^{58}$ karena tidak semua prihal yang tampak tersebut mencerminkan keperibadian individu secara utuh.

\footnotetext{
${ }^{54}$ Menurut Allport, Sikap adalah, "keadaan mental dan saraf dari kesiapan, yang diatur melalui pengalaman yang memberikan pengaruh dinamik atau terarah terhadap respon individu pada semua objek dan situasi yang berkaitan dengannya". Sears, dkk. Psikologi Sosial. (Jakarta: Erlangga, 2006), hlm. 137.

${ }^{55}$ Dalyono, Psikologi Pendidikan, (Jakarta: Rineka Cipta, 2010), hlm. 210.

${ }^{56}$ Terdapat pada QS. Al -Isra' : 70.

${ }^{57}$ Murthadha Muthahari, Persfektif al-Qur'an tentang Manusia dan Agama, (Bandung : Mizan, 1992), hlm. 117.

${ }^{58}$ Harun Nasution, Islam Ditinjau Dari Berbagai Aspek, (Jakarta: UI Press,2001), hlm.30.
} 
Dalam proses pembelajaran guru pendidikan agama Islam, banyak sekali perilaku-perilaku psikologis yang harus dipahami oleh guru. Untuk dapat memahami berbagai aspek psikologis perilaku belajar peserta didik, ${ }^{59}$ seorang guru pendidikan agama Islam, harus memahami aneka prinsip psikologi, terkhusus psikologi pembelajaran agama Islam. Sosok kepribadian guru yang ideal menurut Islam telah ditunjukkan pada keguruan Rasulullah saw. yang bersumber dari alQur'an. Sebagai guru pendidik, sudah sepantasnya apabila keguruan Rasulullah Muhammad saw. dimplementasikan dalam praktik pembelajaran. ${ }^{60}$

Guru merupakan komponen sentral pertama dan utama yang paling menentukan dalam sistem dan model pendidikkan secara keseluruhan. Figur yang satu ini akan senantiasa menjadi sorotan strategis ketika berbicara masalah pendidikan, ${ }^{61}$ karena guru selalu terkait dengan komponen manapun dalam sistem pendidikan. Guru memegang peran figur sentral dalam meningkatkan kualitas pendidikan, khususnya yang diselenggarakan secara fornmal di sekolah. Guru juga sangat menentukan keberhasilan peserta didik, terutama dalam kaitannya dengan proses pembelajaran. ${ }^{62}$

Maka dalam hal mencerdaskan kecerdasan emosi peserta didik, langkah utama yang harus dilakukan guru ialah; harus terlebih dahulu menyadari dan mengenal lebih dekat emosi yang berkembang pada peserta didik. Karena dengan bekal pengenalan yang baik tersebut, seorang guru dapat masuk kelangkah kedua yaitu menjadikan ekspresi emosi ${ }^{63}$ anak didik sebagai pintu masuk kedua untuk menyampaikan moral teaching dalam mempercepat keakraban.

\footnotetext{
59 Belajar adalah proses mental yang aktif untuk mencapai, mengingat, dan menggunakan pengetahuan. Belajar menurut teori koginitif adalah perseptual. Agus Suprijono, Cooperative Learning, Teori dan Aplikasi Paikem, (Yogyakarta: Pustaka Pelajar, 2009), hlm. 22.

${ }^{60}$ Tohirin, Psikologi Pembelajaran Pendidikan Agama Islam, (Jakarta: Raja Grafindo Persada, 2006), hlm. 170.

${ }^{61}$ Keberhasilan pendidikan sangat ditentukan oleh faktor ekstern individu yaitu; lingkungan pendidikan. Harmonisasi lingkungan pendidikan dan kepribadian guru menjadi keniscayaan dalam menumbuhkembangkan potensi murid. Dalam psikologi pendidikan konsep ini dikenal dengan optimisme pedagogis. Ngalim Purwanto, Psikologi Pendidikan, (Bandung: Remaja Rosdakarya, 2003), hlm. 14.

${ }^{62}$ E. Mulyasa, Praktik Penelitian Tindakan Kelas, (Bandung: Remaja Rosda Karya, 2010), hlm. 236.

${ }^{63}$ Bimo Walgito, Pengantar Psikoologgi Umum (Yogyakarta: Andi Offset, 2009), hlm. 140-141.
} 
Pada dasarnya, pendidikan sangat berperan penting, karena hanya dengan proses pendidikanlah manusia dapat mengaplikasikan eksistensinya sebagai manusia mulia, yang nantinya dalam kehidupan manusia pendidikan penting sebagai upaya menanamkan dan mengaktualisasikan nilai-nilai Islam pada kehidupan nyata melalui pribadi-pribadi muslim yang beriman dan bertakwa, sesuai dengan harakat derajat kemanusiaan sebagai pemimpin (khalifah) di muka bumi. ${ }^{64}$

Emosi memang merupakan sebuah gejala normal yang dialami seseorang, yang mendapatkan pressure atau tekanan, sehingga memungkinkan orang tersebut tidak mampu menahan emosinya. Dengan demikian proses berfikir seseorang dalam menghadapi sebuah masalah yang tidak kunjung menemukan jalan keluarnya, seringkali membuat orang tersebut menjadi jenuh. Kejenuhan inilah yang kemudian menghilangkan rasa sabar. Sementara al-Qur'an memerintahkan ummatnya bersabar dalam kondisi dan situasi apapun seperti yang tergambar dalam QS. Al-Baqarah:153.

\section{Epilog}

Manusia dikenal sebagai makhluk dengan emosi dasarnya yang terkait pada perasaan dan kondisi secara biologis maupun psikologis. Emosi dasar yang disenyalir dalam al-Qur'an dengan menggunakan kata khauf (takut), fariha (gembira), dengan segala derifasinya. Dalam mengekspresikan emosi, manusia bisa berprilaku positif maupun negatif. Ekspresi emosi positif merupakan emosi yang menyenangkan. Sedangkan ekspresi emosi negatif tidak diinginkan oleh manusia. Al-Qur'an mengungkapkan masalah emosi senang lebih banyak dan pariatif. Deskripsi emosi senang atau gembira yang tidak hanya terbatas pada peristiwa di dunia tetapi juga di akhirat. Emosi takut dijelaskan berkaitan dengan bencana dan ketakutanketakutan yang berhubungan dengan intrapersonal, interpersonal dan metapersonal.

Mengelola emosi menjadi sesuatu yang urgen bagi perkembangan kepribadian. Maka untuk mengatur emosi dan mengendalikannya diperlukan berbagai langkah dan cara. Beberapa diantaranya adalah pengalihan dari satu obyek ke objek yang lain yang bersifat semu. Dengan zikrullah dan husn al-zan, empati dan

\footnotetext{
${ }^{64}$ Abidin Ibnu Rusn, Pemikiran al-Ghazali Tentang Pendidikan, (Yogyakarta: Pustaka Pelajar, 2009), hlm. 57-58.
} 
menjalankan mekanisme sabar, syukur, pemaaf adalah menjadi solusi dalam mengendalikan emosi-emosi yang tidak diinginkan manusia.

Mengaplikasikan emosi positif dalam ranah pendidikan, seyogyanya memproritaskan unsur-unsur dan faktor psikis. Aspek psikis mempunyai peranan signifikan di lingkup dunia pendidikan khususnya PBM (proses belajar mengajar), karena aktivitas belajar lebih mendominasi dengan intensitas jiwa. Siswa yang emosinya dalam keadaan stabil sangat membantunya dalam perbuatan belajar sehingga perasaan dengan intensitas yaung dominan ketika gejolak emosi yang tidak baik muncul, maka dampak yang diberikannya adalah memberikan implikasi buruk pada pelakunya. Untuk hal tersebut di atas bagi pendidik dalam memahami kondisi peserta didiknya untuk mencapai tujuan. Dengan demikian diharapkan pendidikan dalam perspektif al-Qur'an yang bersifat humanis, sesuai dengan yang di bangun oleh prinsip-prinsip dan spirit al-Qur'an.

\section{Daftar Pustaka}

Al-Atapunang, Manusia dan Emosi, (Maumere: Sekaolah Tinggi Filsafat Ledalero, 2000).

Al-Ashfahanì al-Rāghib, Mu'jam Mufradāt al-Fāz al-Qur'an, (Beirut: Dār al Fikr, 1432H).

Al-'Imadi Abu al-Sa'id Muhammad ibn Muhammad , Irshād al-'Aql al-Salim ilā Mazāyāà al-Qur'ān al-Karìm, (Beirut: Dār Ihyā' alTurāth al-'Arabi, t.t.), Jld. IV.

Bimo Walgito, Pengantar Psikologi Umum, (Yogyakarta: Andi, 2010).

Bobbi De Porter,. Quantum Learning. (New York: Dell Publishing, 1992).

Boeree C. George, Personality Theories, Terj. Inyak Ridwan Muzir, (Jogjakarta: Prismashopie, 2004).

Baharudin, Pendidikan \& Psikologi Perkembangan, (Jogjakarta: ar-Rz Media, 2010).

Conceicao, P., \& Bandura, R, Measuring Subjective Wellbeing: A summary Review of the Literature. (New York: Proquest, 1999).

Carpenito \& Moyet.. Buku saku diagnosis keperawatan (Ed. kesepuluh). (Jakarta: Buku Kedokteran EGC. 2006). 
Chaplin J.P., Kamus Pssikologi, (Jakarta: Raja Grafindo Persada, 2009).

-------------, Kamus Lengkap Psikologi, (Jakarta: Rajawali Pers, 2009), Terj. Katini Kartono.

Diana E Papalia dkk, Human Development, (Jakarta: Salemba Humanika, 2009).

Dalyono, Psikologi Pendidikan, (Jakarta: Rineka Cipta, 2010).

Departemen Pendidikan dan Kebudayaan, Kamus Besar Bahasa Indonesia (Jakarta: Balai Pustaka, 1994).

Dryden Gordon dan Jeanette Vos, Revolusi Cara Belajar, (Bandung: Kaifa, 2001).

Desmita, Psikologi Perekmbangan Peserta Didik, (Bandung: Remaja Rosdakarya, 2011).

Djaali, Psikologi Pendidikan, (Bandung: Bumi Aksara, 2012).

Djamarah, SB. 2002. Prestasi Belajar dan Kompetensi Guru. Surabaya: Usaha Nasional.

Darajat Zakiyah, Ilmu Pendidikan Islam, (Jakarta: Bumi Aksara, 2009).

Effendi Usman, Juhanna S. Praja, Pengantar Psikologi, (Bandung: Aksara, tth).

Effendi E. Usman dan Jyuhaya S. Praja, Pengantar Psikolougi, (Bandung: Angkassa, 1993).

Goleman Daniel, Keccerdasan Emosional, Terj T. Hermaya, (Jakarta: Gramedia Pustaka Utama, 1996).

Kiptiyah, Embriologi dalam al-Qur'an, Kajiann pada Prosess Penciptaan Manusia, (UIN: Malangg Press: 2007).

King, A.L., Psikologi Umum; Sebuah Pandangan Apresiatif, (Jakarta: Salemba Humanika, 2010).

Koppel, R. (2012). Review Essays: Public Policy in Pursuit of Private Happiness. Contemporary Sociology Journal ,2012).

Koeswara E., Teori-teori Kepribadian, (Bandung: Eresco, 1991).

L.F. Barret dkk, 2007, The experience of emotion, Annual Review of Psychology (Vol. 58). Palo Alto, CA: Annual Reviews.

Musa Asy'arie Taufiq Pasiak, Tuhan Empirik dan Kesehatan Spritual, (Yogyakarta : C-NET, 2012).

Miramis, W.F. Catatan Ilmu Kedokteran Jiwa. (Surabaya: Airlangga University Press Theory of Emotion, 1995).

Mahmud, Psikologi Pendidikan, (Bandung: Putaka setia, 2017).

Nasution Harun, Islam ditinjau dari Berbagai Aspeknya, (Jakarta: UI 
Press, 2001).

Al-Nasafí, Abu al-Barakat 'Abd Allah ibn Ahmad ibn Mahmud, Tafsir al-Qur'ān al-Jalìl, (Beirut: al-Amawiyyah, t.t.) Jld. II.

Nata Abuddin, Ilmu Pendidikan Islam, (Jakarta: Kencana, 2012).

Najati M.Usman, Al-Qur'an dan Ilmu-ilmu Jiwa, terj. Ahmad Rofa'i Usmani, (Bandung: Pustaka, 1985).

John W. Santrock, Psychology: The science of Mind and Behavior Lowa, (Lowa : Wm. C. Brown Publishers, 1988)

Mc. Mahon, D. M. (2005, Januari 34). The Quest for Happiness. Retrieved Mei 6, 2017, from Proquest Website: http://proquest.com

Mc. Mahon, D. M. (2005, Januari 34). The Quest for Happiness. Retrieved Januari 6, 2019, from Proquest Website: http://proquest.com

Ott, J. C. Limited Experienced Happiness or Unlimited Expected Utility, What About the Differences? (Journal Happiness Study, 2011).

Mc Mahon, D. M. (2005, Januari 34). The Quest for Happiness. Retrieved Mei 6, 2017, from Proquest Website: http://proquest.com

Koppel, R. (2012). Review Essays: Public Policy in Pursuit of Private Happiness. Contemporary Sociology Journal , 41 (1).

Neufeldt, Victoria, Webster's New Word College Dictionary, $3^{\text {rd }}$ Eds, (New York : Mac Millan References, 1999). Media, 2010.

Muthahari Murthadha, Persfektif al-Qur'ān tentang Manusia dan Agama, (Bandung : Mizan, 1992).

Najib Sulhan, Pendidikan Berbasisi Karakter, (Surabaya: Jepe Press Media Utama, 2010).

Muhaimin H., Manajemen Pendidikan" Aplikasi dalam Penyusunan Rencana Pengembangan Seklah/Madrasah, (Jakarta: Kencana, 2010).

Mulyasa E., Praktik Penelitian Tindakan Kelas, (Bandung: Remaja Rosda Karya, 2010).

Purwanto Ngalim, Psikologi Pendidikan, (Bandung: Remaja Rosdakarya, 2003).

Qushari Yusuf, Kaifa Tsiqatu Binnafsi Kaifa Tuqawwi Tsiqatuka Binafsika, (Mesir; Dar al-Lathif, 2001).

Rodiah dkk, Studi Al-Qur'ān Metode dan Konsep, (Yogyakarta: ELSAQ Press, 2010), 
Rusn Abidin Ibnu, Pemikiran Al-Ghazali Tentang Pendidikan,

(Yogyakarta: Pustaka Pelajar, 2009).

Rochman, L.. Kesehatan mental. (Purwokerto: Stain Press. 2010).

Rahmayulis, Ilmu Pendidikan Islam, (Jakarta: KalamMulia, 2013).

Rosyidi Hamin, Psikologi Kepribadian I, (Surabaya: IAIN Sunan Ampel, 2010).

Sroufe L.A. Bennett, Emotinonal Devlopment Cambridge, (England: Cambridge University Press, 1997).

Syah Muhibbin, Psikologi Pendidikan dengan Pendekatan Baru,(Bandung: Remaja Rosdakarya, 2008).

Stenberg, R.J. Psychology In Search of the Human Mind. (Orlando: Hartcourt College Publishers, 2001).

Seligman, M., Parks, A., \& Steen, T. A Balanced Psychology and a Full Life. (The-Royal-Society Journal, 2004).

Syarifuddin Ahmad, Puasa Menuju Sehat Fisik dan Psikis, (Jakarta: Gema Insani, 2003).

Suryabrata Sumardi, Psikologi Pendidikan, (Jakarta : Raja Grafindo Persada, 2006).

Shaleh, A.R. Psikologi Suatu Pengantar dalam Perspektif Islam.( Jakarta: Kencana, 2004).

Shihab Umar, Kontekstualitas al-Qur'an, (Jakarta: Penamadani, 2005).

Suprijono Agus, Cooperative Learning, Teori dan Aplikasi Paikem, (Yogyakarta: Pustaka Pelajar, 2009).

Santrock, John W Psychology: The science of Mind and Behavior Lowa, (Lowa : Wm. C. Brown Publishers, 1988).

Sumadinata Psikologi Kepribadian, (Jakarta: Rajawali, 2004).

Shiahb M. Quraish, Islam yang Saya Anut: Dasar-dasar Ajaran Islam, (Jakarta: Lentera Hati, 2017).

-------------, Membumikan Al-Qur'ān, Fungsi dan Peranan Wahyu dalam Kehidupan Masyarakat, (Bandung: Mizan, 1993). Perspektif al Quran, (Jakarta: PSQ, 2006).

Suyono \& Hariyanto, Belajar dan Pembelajaran: Teori dan Konsep Dasar, (Bandung : PT Remaja Rosda Karya, 2012).

Sundari. Kesehatan mental dalam kehidupan. (Jakarta: PT. Rineka Cipta. 2005). 
Tim Penyusun, Ensiklopedia al Quran, Jilid 1, (Jakarta: Lentera Hati, 2007).

Tohirin, Psikologi Pembelajaran Pendidikan Agama Islam, (Jakarta: Raja Grafindo Persada, 2006).

Taufiq Muhammad Izzuddin, Panduan Lengkap dan Praktis: Psikologi Islam, Terj. Sari Nurlita dkk, (Jakarta: Gema Insani, 2006).

Tim Penyusun, Ensiklopedia alQur'an, Jilid 2, (Jakarta: Lentera Hati, 2007).

Wasty Soemanto, Psikologi Pendidikan, (Jakarta: Rineka Cipta, 2012).

Warner, R. M., \& Vroman, K. G. (2011). Happiness Inducing Behaviors in Everyday Life An Empirical Assessment of "The How of Happiness". Journal Happiness Study, 12 (1).

Wahab Rohmalina, Psikologi Belajar, (Jakarta: Raja Grafindo Persada, 2015).

Wahab Rohamlian, Psikologi Mengajar, (Jakarta : Raja Grafindo Persada, 2015).

Walgito Bimo, Pengantar Psikologi Umum (Yogyakarta: Andi Offset, 2009).

Yustinus Semiun, Kesehatan Mental, (Yogyakarta: Kanisius, 2010).

Yasyakur Moch, Model Pembelajaran Karakter dalam Perspektif alQur'an, (Jakarta: PTIQ, 2017). 